\title{
Viability of microencapsulated Lactobacillus casei in synbiotic mayonnaise
}

\author{
${ }^{1 *}$ Lieu, M.D., ${ }^{2}$ Dang, T.K.T. and ${ }^{3}$ Nguyen, T.H. \\ ${ }^{1}$ Faculty of Food Technology, Ho Chi Minh city University of Food Industry, Vietnam \\ ${ }^{2}$ Institute of Tropical Biology, Ho Chi Minh city, Viet Nam \\ ${ }^{3}$ Department of Biotechnology, University of Technology, VNU-Ho Chi Minh city, Viet Nam
}

\section{Article history: \\ Received: 26 June 2017 \\ Received in revised form: 16 July 2017 \\ Accepted: 17 July 2017 \\ Available Online: 18 July 2017}

Keywords:

Lactobacillus casei,

Spray drying,

Mayonnaise,

Whey protein,

Maltodextrin,

Galacto-Oligosaccharide

DOI:

http://doi.org/10.26656/

fr.2017.6.103

\begin{abstract}
In this study, whey protein, maltodextrin and GOS (Galacto-oligosaccharides) used as microencapsulating agents to protect Lactobacillus casei during spray-drying and mayonnaise storage. The morphology of microcapsules, $\mathrm{pH}$ charges, the survival rate during mayonnaise storage as well as survival in simulated gastric fluid (SGF) and intestinal fluid (SIF) was tested in this study. The results indicated that whey protein showed a protective effect better than maltodextrin during spray-drying. The particles showed spherical shape and typical concavity of all samples and encapsulating agents were not affected by the size and surface structure of particles. The $\mathrm{pH}$ charges were not significantly different in all mayonnaise samples in this test. The viability of free cell $L$. casei after 6 weeks storage was significant decrease about $4 \log$ CFU/g compared to 1.55 to $3.27 \log \mathrm{CFU} / \mathrm{g}$ in the mayonnaise samples containing microcapsules in which maltodextrin showed the lowest of $L$. casei survival rate. In SGF and SIF conditions, maltodextrin act as prebiotic sufficiently which do not need adding GOS. The combination of whey protein and maltodextrin in which maltodextrin plays a role as supporting agents for the spray-drying process as well as prebiotic potential, while whey protein with high buffer property which enhancing the survival rate of $L$. casie in low $\mathrm{pH}$.
\end{abstract}

\section{Introduction}

Probiotic has been defined as "Live microorganisms (bacteria or yeasts), which when ingested or locally applied in sufficient numbers confer one or more specified demonstrated health benefits for the host" (FAO/WHO, 2001). Because of their health benefits, incorporation of probiotic bacteria into food to enhance the therapeutic value of food products are very interesting, such as yogurt, mayonnaise. (Ali and Esam, 1998; Maryam et al., 2012; Adja et al., 2014). Addition, Prebiotics are non-digestible dietary ingredients that benefit the host by selectively stimulating the growth and/or activity of beneficial bacteria in the colon, whereas synergistic combinations of probiotic and prebiotics are called synbiotics (Michael et al., 2008). To achieve the health benefits, however, probiotic bacteria must be stable in the product as well as survive in large numbers through the digestive tract, to the appropriate location and have beneficial effects for the host (Roy,
2005). The research on probiotic microencapsulated techniques which enhance the viability of probiotic bacteria in adverse conditions is increasing and getting a lot of attention today. The technique of microencapsulation was used commonly in the previous study include extrusion, emulsion, and spray drying techniques which improve the viability of probiotic bacteria in adverse conditions compare to free cells (Won et al., 2001; Akalin et al., 2007; Fabiane et al., 2012; Kartheek et al., 2013). In particular, spray drying technique could make particles which are small size, unaffected organoleptic and easy application on an industrial scale with low cost (Adja et al., 2014). However, it is surprising that in spite of well documented of extrusion and emulsion technique to protect the probiotic bacteria in mayonnaise, there is no report in the literature on using the spray-drying technique to protect probiotic bacteria in mayonnaise. In the previous studies, whey protein, skim milk and maltodextrin showed effectiveness in improving the viability of probiotic 
bacteria (Carlise et al., 2012; Fabiane et al., 2012; Adja et al., 2014). The survival rate of probiotic is not only affected by spray drying conditions, carrier but also affected by strain probiotic using (Paéz et al., 2012). Therefore, evaluation of the role of the carrier should be carried out on the same probiotic bacteria as well as the spray drying condition. In the present study, Lactobacillus casei VTCC AS 186 was microencapsulated by spray-drying in which whey protein, maltodextrin and prebiotic GOS (GalactoOligosaccharide) as wall material. The microcapsules were evaluated the morphology of particles and adding to mayonnaise. The $\mathrm{pH}$ charges, the survival rate of $L$. casei during mayonnaise storage as well as survival in simulated gastric fluid (SGF) and intestinal fluid (SIF) were tested in this study.

\section{Materials and methods}

\subsection{Bacterial strain and culture conditions}

Lactobacillus casei VTCC AS 186 were harvested from $500 \mathrm{ml}$ of a 20 -h culture (late log phase) by centrifugation at $5000 \mathrm{rpm}$. Then, the cells were used in the microencapsulation process in the next step.

\subsection{Spray-drying of L. casei}

Microencapsulated $L$. casei was carried out as assay previously described (Adja et al., 2014) with slight modifications. Briefly, whey protein (Meggle, Germany), maltodextrin (Roquette, France), GOS (Galacto-oligosaccharides; PureBulk, USA) were used as protective agents. The samples, including $\mathrm{W}$ (whey protein $10 \% \mathrm{ww} / \mathrm{v}), \mathrm{M}$ (maltodextrin $10 \% \mathrm{w} / \mathrm{v}), \mathrm{WM}$ (whey protein $8 \% \mathrm{w} / \mathrm{v}$ and maltodextrin $2 \% \mathrm{w} / \mathrm{v}$ ), WG (whey protein $8 \% \mathrm{w} / \mathrm{v}$ and GOS $2 \% \mathrm{w} / \mathrm{v}$ ) and $\mathrm{MG}$ (maltodextrin $8 \% \mathrm{w} / \mathrm{v}$ and GOS $2 \% \mathrm{w} / \mathrm{v}$ ) were evaluated in this study.

The spray-drying of cell suspensions was performed in a laboratory scale spray dryer (Mini spray dryer SD06AG, Labplant UK), using the following process parameters: inlet temperature $=110^{\circ} \mathrm{C}$, outlet temperature $=60-65^{\circ} \mathrm{C}$, spraying rate $=4.5 \mathrm{ml} / \mathrm{min}$. The survival rate of $L$. casei after spray-drying was evaluated by the following equation:

$$
\text { Survival }(\%)=\frac{\sum \log C F U_{\text {after spray-drying }}}{\sum \log C F U_{\text {before spray }- \text { drying }}} \times 100 \%
$$

The preparations after spray-drying were visualized with a scanning electron microscope (SEM). Microencapsulating particles size were evaluated by HORIBA LA-920 machine

\subsection{Mayonnaise preparation}

Mayonnaise was prepared using the following formula: soybean oil $74 \%$, egg $14 \%$, vinegar $(5 \% \mathrm{w} / \mathrm{v})$ $10 \%$, salt $1 \%$, sugar $1 \%$ and white pepper $0.2 \%$. Sugar and vinegar mixed together and then all other ingredients except oil were added and stirred homogeneously. The oil was added very slowly, while stirring homogeneously. Finally, preparations were added into mayonnaise and storage at $4^{\circ} \mathrm{C}$.

The $\mathrm{pH}$ of mayonnaise samples and the survival rate of $L$. casei during storage were determined after storing immediately as well as the end of every 7 days until 42 days of storage at $4^{\circ} \mathrm{C}$.

\subsection{Survival rate of free and microencapsulated bacteria in simulated gastric condition}

The survival rate of free and microencapsulated bacteria incorporated into mayonnaise was tested for acid and bile salts tolerance after 42 days of storage. Simulated gastric fluid (SGF) consisted of $9 \mathrm{~g} / 1$ of sodium chloride containing $3 \mathrm{~g} / 1$ of pepsin (Himedia) was adjusted to $\mathrm{pH} 2.5$ with $5.0 \mathrm{M} \mathrm{HCl}$. Simulated intestinal fluid (SIF) consisted of $9 \mathrm{~g} / 1$ sodium chloride containing $3 \mathrm{ml} / 1$ of bile salts was adjusted to $\mathrm{pH} 6.5$ with $5.0 \mathrm{M} \mathrm{NaOH}$. The viability of $L$. casei in mayonnaise samples was evaluated after 2 hours incubated in SGF and 4 hours incubated in SIF. The samples containing free $L$. case $i$ were used as a control. The survival rate of L. case $i$ was evaluated by the following equation:

$$
\text { Survival }(\%)=\frac{\sum \log C F U_{\text {after incubation }}}{\sum \log C F U_{\text {before incubation }}} \times 100 \%
$$

\subsection{Statistical analysis}

The data were subjected to analysis of variance (ANOVA) using Statgraphics 15 followed by Tukey test to compare means, with a significance level of $5 \%$ when the significant difference between treatments was noted. All tests were performed in triplicate and the data expressed as means \pm standard deviation.

\section{Results and discussion}

\subsection{The effect of spray-drying process on the viability of L. casei}

The viability of $L$. casei before and after spray drying is shown in Table 1. The results showed that the survival rate of $L$. casei after spray drying in five samples including $\mathrm{W}, \mathrm{M}, \mathrm{WM}, \mathrm{WG}$, and $\mathrm{MG}$ was $82.88 \% ; 76.07 \% ; 82.11 \% ; 80.68 \%$ and $77.83 \%$. The viability of $L$. casei in $\mathrm{M}$ sample and MG sample were lower compared to the other samples in this test. Figure 1 
shows the SEM micrographs of $L$. casei preparations with different microencapsulating agents. The particles showed spherical shape and typical concavity of all samples. Microcapsules from all samples are various sizes from $3 \div 12 \mu \mathrm{m}$ and an average size of $6.2 \div 6.5 \mu \mathrm{m}$.

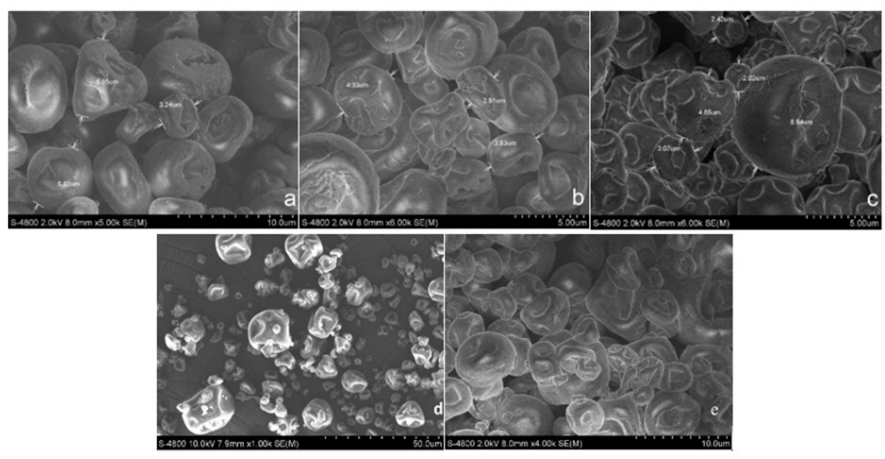

Figure 1. Scanning electron micrograph and surface morphology of preparations (Figure 1a, 1b, 1c, 1d and 1e: $\mathrm{WM}, \mathrm{W}, \mathrm{M}, \mathrm{MG}$ and $\mathrm{WG}$ samples)

The phenomenon of the concave surface of the particle has been reported in previous studies. This phenomenon depends on spray-drying temperature and normal drying process, causing dents on the surface and the surface structure of microcapsules is not affected by the microencapsulating agents (Carlise et al., 2012). In a study by O'Riordan et al. (2001) showed that the sizes of the microcapsules which modified starch used as the wall material were approximately $5 \mu \mathrm{m}$ on average. The microcapsules size about $5.6 \div 5.9 \mu \mathrm{m}$ with natural starch as wall material was also reported by Sandra et al. (2014). The research team indicated that the size of the microcapsules was not affected by the wall material concentration and inlet temperature during the spraydrying process (Sandra et al., 2014). In the present study showed that different encapsulating agents were not affected to the size and surface structure of microcapsules (Figure 1). The size of microcapsules less than $10 \mu \mathrm{m}$ is an ideal size to not affect organoleptic when adding to food (O'Riordan et al., 2001).

The survival rate of probiotic bacteria plays an important role. The amounts of microcapsules which need to add into food products would be decreased when the viability of probiotic during spray-drying is high. In the spray drying, the high inlet and outlet temperature affect significantly to the viability of probiotic bacteria (Sandra et al., 2014). The survival rate of probiotic bacteria reduced nearly $55 \%$ when the inlet temperature was $130^{\circ} \mathrm{C}$ (Kartheek et al., 2013) and up to $80 \%$ when the inlet temperature was $150^{\circ} \mathrm{C}$ (Sandra et al., 2014) but the survival rate would be up to $81 \%$ when the inlet temperature was $100^{\circ} \mathrm{C}$ (Kartheek et al., 2013). Adja et al. (2014) who found that higher spray drying temperatures leading to reduce the viability of $B$. animalis BI-07 and darker color products (Adja et al., 2014). Similarly, the outlet temperature increase from $70^{\circ} \mathrm{C}$ to $100^{\circ} \mathrm{C}$ leading to the survival rate of $L$. rhamnosus reduce from $70 \%$ to $10 \%$ (Ananta, 2005). In the present study, an inlet temperature of $110^{\circ} \mathrm{C}$ showed good protective effect during spray drying (Table 1). The low inlet temperature (below $100^{\circ} \mathrm{C}$ ) makes the product yield that was not dry due to high moisture (O'Riordan et al., 2001). To limit the impact caused by the high temperature of the spray drying process, the choice of microencapsulating agents is very important. Sandra et al. (2014) reported that aggregation of natural starch in spray drying process improved the survival rate of $L$. rhamnosus better than inulin (Sandra et al., 2014). Similar, spray drying process resulted in denaturation and aggregation of whey protein, leading to formed probiotic protecting walls during storage condition (Millqvist, 2001). According to Kartheek et al. (2013) maltodextrin showed protective effect which can reduce the caking and stickiness to the spray dryer's walls (Kartheek et al., 2013). Adja et al. (2014) indicated that maltodextrin, milk protein and fat use as microencapsulating agents may have protected the microorganisms during the drying process (Adja et al., 2014). In the present study, the viability of $L$. casei in M sample was lower than $\mathrm{W}$ and WM samples. This result revealed that whey protein showed protective effect better than maltodextrin (Table 1). The amount of powder from WM was slightly higher than the $\mathrm{W}$ sample (data not shown). However, the survival rate of L.casei was not significantly different between two groups $(p>0.05)$ (Table 1).

Table 1. The average particle size and viability of Lactobacillus casei during spray-drying

\begin{tabular}{|c|c|c|c|}
\hline \multirow{2}{*}{$\begin{array}{c}\text { Wall } \\
\text { material } \\
(\mathrm{w} / \mathrm{v})\end{array}$} & \multicolumn{2}{|c|}{$\begin{array}{c}\text { Total probiotic counts Log } \\
\text { CFU } \\
\end{array}$} & \multirow{2}{*}{$\begin{array}{c}\text { Average } \\
\text { particle size } \\
\qquad(\mu \mathrm{m})\end{array}$} \\
\hline & $\begin{array}{l}\text { Before spray- } \\
\text { drying }\end{array}$ & $\begin{array}{l}\text { After spray- } \\
\text { drying }\end{array}$ & \\
\hline W & $13.55 \pm 0.18^{\mathrm{a}}$ & $11.23 \pm 0.11^{\mathrm{a}}$ & 6.5 \\
\hline M & $13.73 \pm 0.13^{\mathrm{a}}$ & $10.53 \pm 0.17^{b}$ & 6.3 \\
\hline WM & $13.64 \pm 0.10^{\mathrm{a}}$ & $11.21 \pm 0.12^{\mathrm{a}}$ & 6.2 \\
\hline WG & $13.51 \pm 0.16^{\mathrm{a}}$ & $10.90 \pm 0.18^{b}$ & 6.3 \\
\hline MG & $13.49 \pm 0.18^{\mathrm{a}}$ & $10.50 \pm 0.17^{\mathrm{b}}$ & 6.2 \\
\hline
\end{tabular}

Results are expressed as mean $\pm \mathrm{SD} ;(\mathrm{n}=3)$

${ }^{\mathrm{ab}}$ Means in the same column followed by different superscripts are significantly different $(p<0.05)$. W: whey protein $10 \%$; M: maltodextrin 10\%; WM: whey protein $8 \%+$ maltodextrin $2 \%$; WG: whey protein $8 \%+$ GOS $2 \%$; MG: maltodextrin $8 \%+$ GOS $2 \%$ 
$3.2 \mathrm{pH}$ changes and viability of $L$. casei in mayonnaise during storage

The change in the population of nonmicroencapsulated versus micro-encapsulated $L$. case $i$ is shown in Figure 2. It was observed that, the viability of free cell $L$. casei after 6 weeks of storage was significant decreased about $4 \log \mathrm{CFU} / \mathrm{g}$ compared to 1.55 to 3.27 $\log \mathrm{CFU} / \mathrm{g}$ in the mayonnaise samples containing microcapsules in which viable $L$. casei in M sample was lowest and there were no significant differences $(p>0.05)$ among W, WG and WM samples (Figure 2).

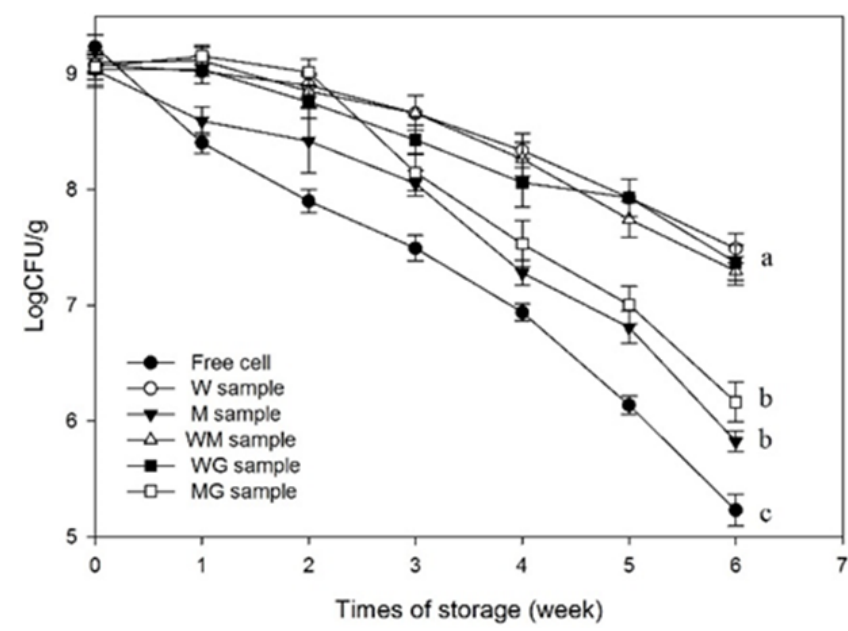

Figure 2. The viability of $L$. casei in mayonnaise during storage ( ${ }^{\mathrm{abc}}$ Means in the same column followed by different superscripts are significantly different $(p<0.05))$. W sample: whey protein $10 \%(\mathrm{w} / \mathrm{v}) ; \mathrm{M}$ sample: maltodextrin $10 \%(\mathrm{w} / \mathrm{v})$; WM sample: whey protein $8 \%$ $(\mathrm{w} / \mathrm{v})+$ maltodextrin $2 \%(\mathrm{w} / \mathrm{v})$; WG sample: whey protein $8 \%(\mathrm{w} / \mathrm{v})+$ GOS 2\% (w/v); MG sample: maltodextrin $8 \%$ $(\mathrm{w} / \mathrm{v})+\operatorname{GOS} 2 \%(\mathrm{w} / \mathrm{v})$

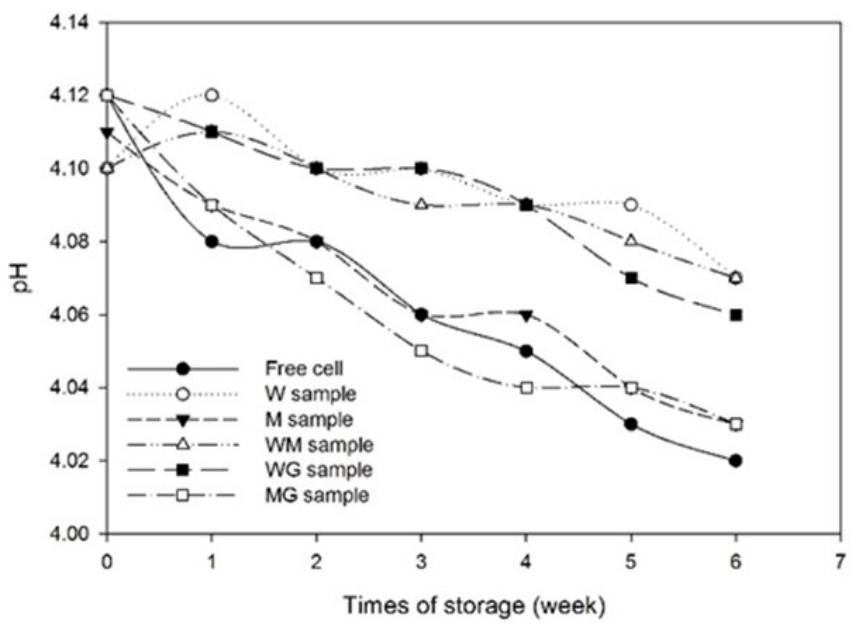

Figure 3. The $\mathrm{pH}$ changes during storage

W sample: whey protein $10 \%(\mathrm{w} / \mathrm{v}) ; \mathrm{M}$ sample: maltodextrin $10 \%(\mathrm{w} / \mathrm{v})$; WM sample: whey protein $8 \%$ $(\mathrm{w} / \mathrm{v})+$ maltodextrin $2 \%(\mathrm{w} / \mathrm{v})$; WG sample: whey protein $8 \%(\mathrm{w} / \mathrm{v})+$ GOS $2 \%(\mathrm{w} / \mathrm{v})$; MG sample: maltodextrin $8 \%$ $(\mathrm{w} / \mathrm{v})+\operatorname{GOS} 2 \%(\mathrm{w} / \mathrm{v})$

The $\mathrm{pH}$ changes during storage are shown in Figure
3. The initial $\mathrm{pH}$ values for all the samples were about 4.10 to 4.12 and there was a decrease in $\mathrm{pH}$ during storage for all the samples. After 7 weeks of storage, the final $\mathrm{pH}$ of mayonnaise were $4.07 ; 4.03 ; 4.07 ; 4.06 ; 4.02$ and 4.03 respectively for W; M; WM; WG; $\mathrm{MG}$ and free cell samples. The results showed that whey protein could help maintain the $\mathrm{pH}$ of the mayonnaise during storage better than maltodextrin.

The $\mathrm{pH}$ changing during storage was reported in previous studies. Maryam et al. (2012) reported that $\mathrm{pH}$ changing of mayonnaise containing free cells or encapsulated cell were not significantly different ( $p>0.05)$ after 30 days of storage (Maryam et al., 2012). In the present study, however, we are in good agreement with Khalil et al. (1998) and Ding et al. (2008), who concluded that the final $\mathrm{pH}$ of mayonnaise containing encapsulated particles was higher than samples containing free cell (Ali et al., 1998; Ding et al., 2008). In low $\mathrm{pH}$ condition, free probiotic bacteria could still utilize carbohydrates and produce small amounts of organic acids leading to lowering the $\mathrm{pH}$ of the product during storage (Ding et al., 2008). Encapsulation technique with the gel matrix may reduce metabolic activity of probiotic in mayonnaise and yogurt products, thereby $\mathrm{pH}$ was higher than the $\mathrm{pH}$ of the sample with non-encapsulated cells (Akalin et al., 2007; Ding et al., 2008).

In previous studies, Probiotic bacteria have also shown no ability to survive in mayonnaise (Maryam et al., 2012; Ali et al., 2014). It is due to intrinsic properties of mayonnaise such as low $\mathrm{pH}$, refrigerated $\left(4^{\circ} \mathrm{C}\right)$ storage. These factors have caused cell death during storage. Khalil et al. (1998) showed that none of nonencapsulated $B$. bifidum in mayonnaise survived after 2 weeks of storage, whereas the amount of encapsulated cells by emulsion technique was only reduced by about $1.4 \log$ CFU/g after 6 weeks of storage (Ali et al., 2014). Similarly, the viability of encapsulated cell of emulsion technique showed higher than non-encapsulated cells in mayonnaise containing $L$. casei and B. bifidum about 2 $\log$ and $5 \log$ cycles respectively after 30 days of storage (Maryam et al., 2012).

In the present study, the viability of $L$. casei in microcapsules was 0.8 to $2.41 \log$ CFU higher than the free cell (Figure 2). The result indicated that L. casei could resist the low $\mathrm{pH}$ and the viability of probiotic bacteria in mayonnaise was depend on the type of strain and microencapsulated technique. Emulsion technique with bigger size particles which can protect probiotic bacteria from the penetration of ion $\mathrm{H}^{+}$better than spray 
drying technique. However, microencapsulating agents play an important role in protecting probiotics from adverse conditions. In the present study showed that the amount of microencapsulated $L$. casei in $\mathrm{W}$ and $\mathrm{WM}$ samples were above recommended for probiotic food after 6 weeks storage which equal to or greater $6 \log$ $\mathrm{CFU} / \mathrm{g}$ (Roy, 2005). This suggests that whey protein could improve the viability of probiotic during storage.

\subsection{Viability of L. casei in SGF and SIF after 6 weeks of storage}

After 6 weeks of storage, the mayonnaise samples were tested for its survival in simulated gastric conditions. The effect of SGF ( $\mathrm{pH} 2.5)$ and SIF on the viability of free cell and microencapsulated $L$. casei were shown in Table 2. There were significant differences $(\mathrm{p}<0.05)$ between the free cell and microencapsulated $L$. casei. The viable cell numbers of free $L$. casei rapidly decreased from $100 \%$ to $49.87 \%$ after 4 hours incubated in SIF and none of the free cells survived after 2-hour incubation in SGF (Table 2). In W, M; WM; WG; MG samples, the viability of $L$. casei remained $75.74 \%$; $69.65 \% ; 78.41 \% ; 75.35 \% ; 75.63 \%$ after 4 hours incubation in SIF and 55.20\%; 33.92\%; 68.83\%; $67.35 \% ; 45.70 \%$ after 2 hours incubation in SGF respectively (Table 2).

Table 2. Viability of Lactobacillus casei in SGF and SIF after 6 weeks of storage

\begin{tabular}{|c|c|c|c|c|c|}
\hline \multirow[b]{2}{*}{$\begin{array}{l}\text { Mayonna } \\
\text { ise } \\
\text { Sample }\end{array}$} & \multicolumn{5}{|c|}{$\begin{array}{l}\text { Lactobacillus casei cell counts in mayonnaise } \\
(\log \mathrm{CFU} / \mathrm{g})\end{array}$} \\
\hline & Initial & $\begin{array}{c}\text { After } \\
\text { incuba } \\
\text { tion in } \\
\text { SIF }\end{array}$ & $\begin{array}{c}\text { Surviva } \\
1 \text { rate } \\
(\%)\end{array}$ & $\begin{array}{c}\text { After } \\
\text { incubat } \\
\text { ed in } \\
\text { SGF }\end{array}$ & $\begin{array}{c}\text { Surviva } \\
1 \text { rate } \\
(\%) \\
\end{array}$ \\
\hline W & $\begin{array}{c}7.49 \pm \\
0.12\end{array}$ & $\begin{array}{c}5.67 \pm \\
0.12\end{array}$ & $\begin{array}{c}75.74 \pm \\
0.69^{\mathrm{a}}\end{array}$ & $\begin{array}{c}4.13 \pm \\
0.14\end{array}$ & $\begin{array}{c}55.20 \pm \\
2.35^{\mathrm{a}}\end{array}$ \\
\hline M & $\begin{array}{c}5.82 \pm \\
0.09\end{array}$ & $\begin{array}{c}4.05 \pm \\
0.15\end{array}$ & $\begin{array}{l}69.65 \pm \\
1.62^{\mathrm{b}}\end{array}$ & $\begin{array}{c}1.98 \pm \\
0.16\end{array}$ & $\begin{array}{l}33.92 \pm \\
2.26^{\mathrm{b}}\end{array}$ \\
\hline WM & $\begin{array}{c}7.30 \pm \\
0.12\end{array}$ & $\begin{array}{c}5.72 \pm \\
0.12\end{array}$ & $\begin{array}{l}78.41 \pm \\
2.3^{\mathrm{a}}\end{array}$ & $\begin{array}{c}5.02 \pm \\
0.14\end{array}$ & $\begin{array}{c}68.83 \pm \\
0.90^{\mathrm{c}}\end{array}$ \\
\hline WG & $\begin{array}{c}7.37 \pm 0 \\
.15\end{array}$ & $\begin{array}{c}5.55 \pm \\
0.13\end{array}$ & $\begin{array}{r}75.35 \pm \\
0.81^{\mathrm{a}}\end{array}$ & $\begin{array}{c}4.96 \pm 0 \\
.15\end{array}$ & $\begin{array}{c}67.35 \pm 1 \\
.19^{c}\end{array}$ \\
\hline MG & $\begin{array}{c}6.16 \pm 0 \\
.17\end{array}$ & $\begin{array}{c}4.66 \pm \\
0.24\end{array}$ & $\begin{array}{l}67.35 \pm \\
1.19^{\mathrm{b}}\end{array}$ & $\begin{array}{c}2.81 \pm 0 \\
.17\end{array}$ & $\begin{array}{l}45.71 \pm 2 \\
.68^{\mathrm{b}}\end{array}$ \\
\hline Free cell & $\begin{array}{c}5.23 \pm \\
0.14 \\
\end{array}$ & $\begin{array}{c}2.61 \pm \\
0.18\end{array}$ & $\begin{array}{l}49.87 \pm \\
2.06^{\mathrm{c}} \\
\end{array}$ & 0 & $0^{\mathrm{d}}$ \\
\hline
\end{tabular}

Results are expressed as mean $\pm \mathrm{SD} ;(\mathrm{n}=3)$

${ }^{a b c}$ Means in the same column followed by different superscripts are significantly different $(p<0.05)$

W sample: whey protein $10 \%(\mathrm{w} / \mathrm{v}) ; \mathrm{M}$ sample: maltodextrin $10 \%(\mathrm{w} / \mathrm{v})$; WM sample: whey protein $8 \%$ $(\mathrm{w} / \mathrm{v})+$ maltodextrin $2 \%(\mathrm{w} / \mathrm{v})$; WG sample: whey protein $8 \%(\mathrm{w} / \mathrm{v})+$ GOS $2 \%(\mathrm{w} / \mathrm{v}) ;$ MG sample: maltodextrin $8 \%$ $(\mathrm{w} / \mathrm{v})+\operatorname{GOS} 2 \%(\mathrm{w} / \mathrm{v})$
O'Riordan et al. (2001) indicated that microencapsulated $B$. bifidum by spray drying with starch $(10 \% \mathrm{w} / \mathrm{v})$ as wall materials was not improved the viability of $B$. bifidum in SGF and SIF compared to the free cell (O'Riordan et al., 2001). However, Fabiane et al. (2012) showed that the protective effect of whey protein which used as microencapsulating agents on Bifidobacterium in SGF condition better than nonmicroencapsulated. Skim milk and whey protein have the ability to limit the influence of $\mathrm{H}^{+}$ions due to high buffer properties (Won et al., 2001; Akalin et al., 2007). Combination of alginate 3\% (w/v) and skim milk $0.6 \%$ (w/v) maintained $\mathrm{pH}$ of preparations (above 4) for 20 minutes incubating in $\mathrm{pH} 1.5$ (Won et al., 2001). Similar, Akalin et al. (2007) indicated that high buffer properties of whey protein concentration which adding to reducedfat yogurts could make $\mathrm{pH}$ value higher than control samples during 28 days of storage (Akalin et al., 2007). This suggests that the viability of probiotic bacteria depends on the type of microencapsulated agents.

In the present study, it is interesting to note that the viability of microencapsulated $L$. casei in $\mathrm{WM}, \mathrm{W}$ and WG samples were no significant difference $(p>0.05)$ during storage (Figure 2), but the survival rate of $L$. casei in $\mathrm{W}$ sample was significantly lower $(p<0.05)$ than WM and WG samples after 2 hours incubation in SGF (Table 2). Karrtheek et al. (2013) suggested that maltodextrin plays a role as supporting agents for the spray-drying process as well as prebiotic potential (Kartheek et al., 2013). According to Iyer et al. (2005), probiotic bacteria have an efficient metabolic mechanism to prebiotic than simple sugar (Iyer and Kailasapathy, 2005). It's suggested that, maltodextrin act as prebiotic sufficiently which do not need to add GOS. The viability of $L$. casei during spray-drying in which maltodextrin act as wall material showed better than GOS (Table 1). Therefore, the combination of whey protein and maltodextrin as wall materials, eventually leading to has dual efficiency: First, the denaturation and aggregation of whey protein leading to formed probiotic protecting walls during spray -drying process and storage condition; Second, maltodextrin's role as prebiotic potential and high buffer properties of whey protein may improve the viability of L. casei in SGF and SIF conditions.

\section{Conclusion}

In conclusion, the present study indicated that the viability of $L$. casei was affected significantly by microencapsulated agents during spray-drying, storage and in SGF and SIF conditions. The size and surface structure of microcapsules were not affected by 
microencapsulating agents. The viable counts of $L$. casei with whey protein as wall material was higher than maltodextrin. Prebiotic enhanced significantly the viability of $L$. casei in SGF and SIF in which maltodextrin act as prebiotic sufficiently which do not need adding GOS. Maltodextrin's role not only as a wall material in microencapsulation but also as a prebiotic potential, eventually leading to a combination of whey protein and maltodextrin provided an excellent protection of $L$. casei cells from adverse conditions.

\section{Acknowledgment}

The authors gratefully acknowledge Ho Chi Minh City University of Food Industry for the financial support

\section{References}

Adja, C.L.M., Marcelo, T., Alexandre, U., Roberta, T.P.C. and Carmen, S.F.T. (2014). Structural characterisation and cell viability of a spray dried probiotic yoghurt produced with goats' milk and Bifidobacterium animalissubsp. lactis (BI-07). International Dairy Journal, 39, 71-77.

Akalin, A.S., Gönç, S., Unal, G. and Fenderya, S. (2007). Effects of fructooligosaccharide and whey protein concentrate on the viability of starter culture in reduced-fat probiotic yogurt during storage. Journal of Food Science, 72, 222-227.

Ali, H.K. and Esam, H.M. (1998). Alginate Encapsulated Bifidobacteria Survival in Mayonnaise. Journal of Food Science, 63(4), 702-705.

Ananta, E., Volkert, M. and Knorr, D. (2005). Cellular injuries and storage stability of spray-dried Lactobacillus rhamnosus GG. International Dairy Journal, 15, 399-409.

Carlise, B.F., Elane, S.P., Renata, D.M.C. A., Stephanie, S.P., Aureanna, N.N. and Fabio, S.M. (2012). Microencapsulation of Bifidobacteria by spray drying in the presence of prebiotics. Food Research International, 45, 306-312.

Ding, W.K. and Shah, N.P. (2008). Survival of Free and Microencapsulated Probiotic Bacteria in Orange and Apple Juices. International Food Research Journal, $15,219-232$

FAO/WHO. 2001. Experts' Report. Health and nutritional properties of probiotics in food including powder milk with live lactic acid bacteria. Rome: FAO

Fabiane, P.D.C.C., Carina, D.R.E.S., Carlise, B.F.F.,
Juliana, G.L. and Ernani, S.S.A. (2012). Bifidobacterium Bb-12 microencapsulated by spray drying with whey: Survival under simulated gastrointestinal conditions, tolerance to $\mathrm{NaCl}$, and viability during storage. Journal of Food Engineering, 113, 186-193.

Iyer, C. and Kailasapathy, K. (2005). Effect of coencapsulation of probiotics with prebiotics on increasing the viability of encapsulated bacteria under in vitro acidic and bile salt conditions and in yogurt. Journal of Food Science, 70, M18-M23.

Kartheek, A. and Valérie, O. (2013). Optimization of microencapsulation of probiotics in raspberry juice by spray drying. LWT - Food Science and Technology, 50, 17-24.

Maryam, F., Nima, M., Hamed, A., Mohammad, A.K.Z., Fariba, Z.H. and Kasra, B. (2012). Effect of microencapsulation plus resistant starch on survival of Lactobacillus casei and Bifidobacterium bifidum in mayonnaise sauce. African Journal of Microbiology Research, 6(40), 6853-6858.

Michael, D.V. and Schrezenmeir, J. (2008). Probiotics, Prebiotics, and Synbiotics. Advance in Biochemical Engineering/Biotechnology, 111, 1-66

Millqvist, F., Ulla, E. and Björn, B. (2001). Surface composition of spray-dried milk protein-stabilised emulsions in relation to pre-heat treatment of proteins. Colloids and Surfaces B: Biointerfaces, 21, 47-58.

O'Riordan, K., Andrews, D., Buckle, K. and Conway, P. (2001). Evaluation of microencapsulation of a Bifidobacterium strain with starch as an approach to prolonging viability during storage. Journal of Applied Microbiology, 91, 1059-1066.

Roy, D. (2005). Technological aspects related to the use of bifidobacteria in dairy products. Lait, $85,39-56$.

Sandra, V., Avila-Reyes., Francisco, J.G.S., María, T.J., María, F.S.M.G. and Luis, A. B.P. (2014). Protection of $L$. rhamnosus by spray-drying using two prebiotics colloids to enhance the viability. Carbohydrate Polymers, 102, 423-430.

Won, K.Y., Yim, T.B., Lee, K.Y. and Heo, T.R. (2001). Effect of Skim Milk-Alginate Beads on Survival Rate of Bifidobacteria. Biotechnology Bioprocess Engineering, 6, 133-138. 